DOI: 10.7596/taksad.v2i3.271

\title{
Socio-Economic Status, Job Satisfaction and Sector Visions of the Steelworkers: Karabuk Case Study
}

\author{
Sinan Yılmaz ${ }^{*}$, Hür Mahmut Yücer ${ }^{* *}$, Yahya Fidan ${ }^{* * *}$
}

\begin{abstract}
There are many studies focusing on Karabuk province, which is one of the most important iron-steel manufacturing centers in Turkey, and the developing iron-steel sector in this province. This iron-steel sector and Karabuk as a whole have undergone many transformations due to the following factors: the privatization of the national iron-steel factory, Kardemir; the foundation of Karabuk University; and the implementation of training programs for steelworkers and an Iron and Steel Institute for students by Karabuk University. These factors suggest that the changes in Karabuk province are ongoing ones that will have a rapid and favorable effect on the society. To follow this change, it is necessary to have periodic studies of the iron-steel sector in Karabuk. This study empirically examines on such variables as socio-economic status, job satisfaction, and sector visions of the steelworkers.
\end{abstract}

Keywords: Karabuk, Iron-Steel, Job Satisfaction, steelworkers, KARDEMIR.

\footnotetext{
*Karabuk University, elektromektup@gmail.com

** Karabuk University, hurmahmut@gmail.com

**** Marmara University, dryfidan@gmail.com
} 


\section{Introduction}

Karabuk, which was a village consisting of 13 houses during the time of the Ottoman Empire, received extensive immigration with the foundation of an iron-steel factory in 1937. The foundation of the factory led to the growth of Karabuk and it became a town. On March 3, 1953, Karabuk became a part of the Zonguldak province, and on June 6, 1995, it became the $78^{\text {th }}$ province of Turkey (Karakök, 2010:286).

Tracing the increase in the employment of the iron-steel factories provides insight into the growth of city settlements, dwelling-houses for workers, public housing, social facilities and financial development of the city. The number of workers employed in the factories gradually increased: 3,120 in $1941 ; 3,812$ in 1944; more than 4,000 in 1950; and about 8,000 in 1965. The Karabuk Iron-Steel Factory continued to employ more workers between 1970 and 1980. The number of the workers reached 14,755 in 1977-the highest number of employees in the history of the factory. The founding of the Iskenderun Iron and Steel Factory and the transferring of employees from the Karabuk factory to the Iskenderun factory led to a decrease in the number of workers at the Karabuk factory in 1977. The largest decrease in the workforce happened just before the privatization of the Karabuk factory in 1995. The number of the employees diminished from 8,846 in 1986 to 4,765 in 1995. This decrease occurred for a variety of reasons: suspense arising from the uncertainty after the privatization; employment in newly-established public services because of Karabuk's conversion into a city; increase in the need for employment in other areas of the workforce, such as tourism and communication, and diversity in the industry of the developing city. In short, uncertainty resulting from new ownership of the factory led the workforce to seek employment in other sectors (Ersöz, 2000:13-26). The economic crisis also led to a decrease in the population of the Karabuk province and to fewer workers employed by the iron-steel industry. For example, the population of Karabuk fell from 105,374 in 1990 to 100,749 in 2000.

The Karabuk Iron-Steel Factory continued to experience a decrease in its number of workers at the beginning of the 2000s. As of 2003, the total number of full-time and part-time workers was 3,665; it became 3,565 in 2004, 3,247 in 2007 and 3,118 in 2009. During the same time period, 1,291 workers were employed in the rolling mills (private sector) (Demirci, 2010:303-304).

Although the number of workers employed in Kardemir decreased, the iron-steel industry continued to make socio-economic contributions to the city. Kardemir led to the development of rolling mills and different branches of the industry after 1960. These industries not only improved the lines of business, which require expertise, but they also raised the qualifications of the workers. Private rolling mills in the city created entrepreneurship and increased economic input (Gürel-Çamur-Akay, 2010:293-295). 
The construction of permanent houses solved the accommodation problems, which arose with the expansion of the industry. The houses and apartments that were constructed were distributed through a classification process to managers, engineers, officers and workers. Houses with five rooms were constructed with the name of Houses of Managers, while apartments with three, four or five rooms were constructed with the names of 100 Houses, 200 Houses and River Houses (163 Houses).

From 1939 to 1954, the state continued to construct houses for workers: 101 houses in 1939; 172 houses in 1940; 75 houses in 1941; 190 houses in 1942-1943; 145 houses in 1944; 167 houses in 1945; 20 houses in 1946; 50 houses in 1948; seven houses in 1951; seven houses in 1952; and 74 houses in 1953-1954 were constructed. This was planned according to the social realities. Moreover, some facilities that were assumed as luxury for the conditions of Turkey at that time such as a cinema, a turf football pitch, outdoor swimming pool and clubhouses - for free time activities and celebrations such as engagement and wedding ceremonies - were also constructed. Educational facilities for the children of the workers and a hospital were also constructed. Leading role of the factory in official ceremonies and especially sports competitions brought the introduction of the ideology of the new state through working class. In one sense, this situation formed a basis for the construction and transfer of a new life style via a group of people who have a standard income. Therefore, disemployment that took place as a result of industry's losing too much money and privatization process seems to be influential on the ideology of the golden age of Karabuk because although the majority of the workers who lost all of these facilities with the privatization of the industry were dismissed, their memories are still alive (Kütükcüoğlu, 2010: 350-351; Özkan-Çabuk, 2010).

According to the data of the Turkish Statistical Institute in 2008, hourly wage in the production sector in the public institutions was 2,771 Turkish Liras (1550\$) while this wage was 1,870 Turkish Liras (1050\$) in private companies. Hourly wage in the production sector in the public institutions increased $9.9 \%$; wage per person in the production sector increased $18.0 \%$; and wage per person in other sectors increased $16.0 \%$. Hourly wage in the production sector in companies increased $9.9 \%$; wage per person in production sector increased $10.4 \%$; and wage per person in other sectors increased $10.5 \%$.

Today, the technology factor demands an increase in the qualifications of the workers. On the other hand, technology requires less muscle force because of automation and massproduction. This requires fewer workers with more specific, continuous, developing, and multiple trainings. It means that the workers who previously worked with their muscle force are supposed to develop their mental processes, keep up to date and return to school to attend workshops in order to adjust to new machines. After the demands of new technology, a new type of the worker has developed who alternates between school and factory. . 
In primitive societies, even in agricultural societies, working hours, social rights (such as housing for workers), and holidays were considered and arranged according to the potential of the employee or to the job (identification of the worker with his job). On the other hand, workers after being on the job for a while put themselves first (disintegration) by expressing their demands (choice of clothes required by the job, clothing allowance, holiday and overtime pay, provided or paid lunch and cafeteria services). Quality, proportion and intensity of the demands changed depending on the job and according to the worker population in the area. Therefore, there were always new conflicts, the reasons of which changed constantly, between the employers and employees. Workers formed associations in order to protect their rights (labor unions) but the people who were assigned to continue the organized struggle sometimes behaved according to their ideological ideas and the conflicts resulted in grievance of employers and employees again.

Environment gained importance in parallel with the liberalist transformation in societies after World War II (post-modernism) and this created egocentrism. This situation brought the pressure of endless demands on limited products/production. Namely, change of consumption habits has shown that production cannot meet the demands despite the variation and increase in it. In the new era, the notion that all people are equal in all fundamental rights and liberties was perceived as being equal even if they do not produce as much and led the idea of insisting on their demands. Thus, while the workers' riots became limited with union rights (strike and lockout) they also participated in student riots. Bipolar ideologies supported this participation in the nation-state process. Supporters of Marxist theory, who belonged to one of the most influential ideologies of the era, looked at all events and facts from a socioeconomic basis, putting the working class at the center and foreseeing their governance of the country. Therefore, all organizational structures were supposed to be either directed according to the views of the workers or left to their management. Workers' governance would be able to bring real social justice and parity. However, production and consumption structures (supply and demand) were too complex to be shaped only by workers and employers. Moreover, if the workers had been the managers, they would have also received similar objections. The problems were too complex and varied to be dealt with only with explanations of sociological terms of "demands for rights" and "solving conflicts."

It is commonly said in the industrial age that production increases became possible by using more rational wage policies. What is the rate of wage increase and did any other factors affect this increase? Why does a worker demand a higher wage? In which organizations do the workers focus on wage increase and in which ones do the demands vary? It seems that the demands focus on wage increase in the industrial environments where there is no transparency, no clear information about the aims, and necessary social needs are not met (transportation, accommodation, working conditions). The demands are directed to secondary social rights in the organizations in which these needs are met. In this case, wage increase for 
vital needs is followed by the demand for a better social environment. A better social environment brings more qualified socio-cultural demands. Comparison of wages and social rights in similar business lines, implemented or planned improvements, identification of vision and aims of business line and sharing these create a positive communication environment. Briefly, social environment has an important effect on the production. A motivation that aims to maintain the increase in the income and provide a higher social standard can reflect on production in workplaces.

A worker is not only a member of a business group but also a member of vocational, familial, financial or political groups. In fact, human affairs, which are within the sociology of work, discuss workers in such a social environment. To understand this social environment, therefore, requires an understanding of the relationship between the worker and his employer, technology and wages (Castaneda-Heredia, 1993: 14-17). The problems encountered in industrial affairs appear in other societal situations as long as the production moves towards high-tech products, financial and social structures change according to it (TemplemanSchares, 1993: 48-51).

The business life of industrial society has many areas of conflict. Sociologists emphasized a set of business areas in order to narrow down these conflict areas. For example, sociologists identified the workers' commitment to the organization as an important factor in understanding the business life of the industrial society. They described this commitment as "the feelings that a worker feels for his workplace." Although types of commitment vary according to the type of industry, these types generally focus on the following:

a) Type of Emotional Dependence is the dependence element that attracts the greatest interest in organizational dependence literature. Emotional dependence refers to the individual's identification with the organization, involvement in the organization and emotional bond with the organization. In this type of dependence, the organization is both meaningful and crucial for the individual since he sees himself as a part of it. Consequently, individuals involved in the organization experience a sense of happiness due to their membership in the organization (Allen, Meyer, 1990a: 2-6.).

b) Dependence of Continuity is the state of continuation of being a member of the organization resulting from the fact that leaving the organization has a high cost risk. In this type of dependence, the individual cannot leave the organization, no matter what he wants, because leaving will be quite costly and bring with it a set of economic and emotional difficulties. The following factors describe dependence of continuity: the number and quantity of investments in the organization and the workers' perception of alternative work opportunities (Allen, Meyer, 1990a: 3-4.). 
c) Normative Dependence is the type of dependence that relies on convincing the individual that he has responsibilities towards the organization and therefore, making him feel obliged to stay in the organization. The obligation does not stem from economic benefits from the organization, but instead emphasizes a moral obligation to the organization. In other words, the worker stays within the organization because of loyalty-believing that staying is the right and ethical decision (Allen, Meyer, 1990b: 4).

The above-mentioned dependencies develop the worker's connection with his job and decrease the possibility of the worker leaving his job.

In addition to commitment to the organization through a variety of dependencies, "institutional socialization" plays a role in the business life of an industrial society. Institutional socialization, which can be defined as the worker learning the institutional culture and harmonizing with it, is a process during which the newly recruited or newly promoted worker learns the attitudes, values and behaviors expected from him. Therefore, socialization is a way of continuing the present culture with the new workers. The main aim of the socialization activity is to make the worker an active member of the organization (Baysal, 1992: 274). The organization should meet the present needs of the worker and also prepare for the future in terms of people management. In order to do so, human resources management, such as promotions, transfers, disemployment, employment, etc., should be supported with career development efforts and plans. In this case, personal development should be given importance because personal development will contribute to the organization's institutional success. The organization might first focus on the workers' environment before dealing with the development of the individual worker. With this aim, maybe "people's rehabilitation" should be dealed before the personal development. Rehabilitation, besides helping to institutional socialization, will bring self-esteem to the workers and make them see working there as a privilege.

It is anticipated that this study will offer empirical data that will provide ways to narrow the conflict areas and increase the workers' commitment to the institution.

\section{TOPIC, AIM AND METHOD OF THE STUDY}

This study deals with the socio-economic status, job satisfactions, sector visions, working conditions, healthcare services and legal rights of the workers employed in the ironsteel sector. The aim of the study is to collect empirical data about the above-mentioned topics, to examine how those issues affect workers employed in the iron-steel sector and to find ways to solve the problems of the sector. Previous studies were reviewed; data of Turkish Statistical Institute were taken into consideration and empirical results collected by using questionnaire were included in the study. Students studying in the Graduate Department of Sociology both delivered and collected survey forms to the workers. 
Since the study will be published as an article, results of the collected data are presented and evaluated in simple frequency tables without giving detailed information. In addition, results of the variables considered significant as a result of the examination of crosscorrelation tables were included. A statistical program, SPSS, was used to analyze the data.

\section{SETTING AND SELECTION OF THE STUDY GROUP}

Workers working in the Iron-Steel sector in Karabuk province in Turkey constitute the setting of the study. The study only included "blue collar workers." The researchers chose 180 subjects for the study and delivered forms to them. However, only 169 of the subjects returned these forms; after eliminating incomplete forms, the researchers were left with 161 subjects.

\section{FINDINGS}

\section{SOCIO-ECONOMIC STATUS OF THE WORKERS IN THE SECTOR}

Many questions emphasized the socio-economic status of the workers in the sector. This is because the socio-economic status of a person is not only related to the amount of money he earns from his job, but also to other factors in his life. For example, two people might earn the same amount of money, but they could have different expenses due to caregiving responsibilities and endure poorer living conditions. Even individuals who take care of the same number of people might experience a different home situation if one owns his house and the other pays a monthly rent. Moreover, some workers might have additional incomes, such as rental incomes and land incomes that implement their salaries. To raise the family's standard of living also requires that other family members, not just the primary worker, have wage-earning jobs.

Based upon the above-mentioned examples, determining the socio-economic status is quite a difficult and complex task. Therefore, it is important to note that the results of this study - a study that deals with the socio-economic status of the iron-steel workers-are limited to the findings of this particular study.

The study group received four different options that considered conditions in Turkey for responding to the question about the family's income. Each of these options represents a different level of income: 1) lower income levels referred to salaries up to 1000 Turkish Liras; 2) lower middle income levels defined salaries between 1001-1500 Turkish Liras; 3) upper middle income levels included salaries between 1501-2000 Turkish Liras; and 4) high income levels indicated salaries of more than 2000 Turkish Liras

The Table of Level of Income illustrates the monthly incomes of the study group. It shows a high intensity in the lower middle income group (44.7\%) and in the upper middle 
income group (44.0\%). The proportion of the people in the lower income group (5.7\%) and in the high income group (5.7\%) is relatively low. The distribution of these proportions, according to the workers' years of seniority and levels of education, are examined below.

\section{Table 1: Workers' Level of Income}

\begin{tabular}{|llrrr|}
\hline \multirow{3}{*}{ Valid } & & Frequency & Percent & Valid Percent \\
& Between 0-1000 TL & 9 & 5.6 & 5.7 \\
& Between 1001-1500 TL & 71 & 44.1 & 44.7 \\
& Between 1501-2000 TL & 70 & 43.5 & 44.0 \\
& More than 2000 TL & 9 & 5.6 & 5.7 \\
& Total & 159 & 98.8 & 100.0 \\
Missing & Unanswered & 2 & 1.2 & \\
Total & & 161 & 100.0 & \\
& & & & \\
\hline
\end{tabular}

A question about their level of education was asked to the study group (Table 2). Three different options were given to the study group in this question. Among these options, primary school option represents low level of education, high school option represents medium level of education and university option represents high level of education. Besides determining their level of education, our purpose in asking this question is to determine how the findings of the study group differ according to their level of education.

It is observed that the proportion of university graduates is considerably low (5\%). On the other hand, the proportion of primary school graduates is relatively higher than university graduates $(30.4 \%)$ but lower than high school graduates (64.6\%). High school graduates have the greatest proportion. According to these findings, it could be stated that the average level of education of the study group is below the medium level but it is also close to it.

\section{Table 2: Workers' Level of Education}

\begin{tabular}{|llrrr|}
\hline & Frequency & Percent & Valid Percent \\
\hline Valid & Primary School & 49 & 30.4 & 30.4 \\
& High School & 104 & 64.6 & 64.6 \\
& University & 8 & 5.0 & 5.0 \\
Total & 161 & 100.0 & 100.0 \\
\hline
\end{tabular}

Chi-square analysis was used in determining the relation between the level of education and level of income of the study group. Table 3 below indicates that there is a significant relation between the level of income and the level of education because of the fact 
that $\mathrm{P}=0.009$ is higher than 0.05 . This finding parallels the findings of similar research that shows the relationship between levels of education and income (Yilmaz, 2008).

When the table that shows the relation between levels of income and education is examined, it is seen that the proportion of the participants who have lower incomes and lower middle incomes decreases when the level of education increases. It is also worth noting that there aren't any university graduates in the lower income group. As for the upper middle income and high income groups, income increases with education without any exceptions.

For high school and university graduates, income increases with education across all levels of income. However, a sharp fall is seen in the high level of income for both groups. This data contradicts the results of the different studies showing that the level of income increases with the level of education (Y1lmaz, 2008). These findings demonstrate that the two different groups having medium and high levels of education show similar characteristics. It could be claimed that this similarity stems from the fact that people with different levels of education are employed in the same position. But in this case, the workers in this position who have a high level of education have a lower level of income relative to highly educated workers in other sectors.

Table 3: The Relationship between Workers' Level of Education and Level of Income

\begin{tabular}{|c|c|c|c|c|c|c|c|c|}
\hline \multirow{3}{*}{ Level of Income } & \multicolumn{6}{|c|}{ Distributions of Families by Income Levels } & & \\
\hline & \multicolumn{2}{|c|}{$\begin{array}{l}\text { Primary } \\
\text { School }\end{array}$} & \multicolumn{2}{|c|}{ High School } & \multicolumn{2}{|c|}{ University } & \multicolumn{2}{|c|}{ Total } \\
\hline & $\mathrm{N}$ & $\%$ & $\mathrm{~N}$ & $\%$ & $\mathrm{~N}$ & $\%$ & $\mathrm{~N}$ & $\%$ \\
\hline Between 0-1000 TL & 4 & 8.3 & 5 & 4.9 & 0 & 0 & 9 & 5.7 \\
\hline Between 1001-1500 TL & 31 & 64.6 & 39 & 37.9 & 1 & 12.5 & 71 & 44.7 \\
\hline Between 1501-2000 TL & 11 & 22.9 & 53 & 51.5 & 6 & 75 & 70 & 44 \\
\hline More than $2000 \mathrm{TL}$ & 2 & 4.2 & 6 & 5.8 & 1 & 12.5 & 9 & 5.7 \\
\hline Total & 48 & 100 & 103 & 100 & 8 & 100 & 159 & 100 \\
\hline
\end{tabular}

The relation between income and seniority is examined in Table 4 below. Chi-square analysis shows that there is a significant relationship between income and seniority $(\mathrm{P}=0.000)$. Since the Karabuk Iron-Steel Industry was privatized in 1995, studies of the level of income are generally divided into two categories: pre- and post-privatization (www.oib.gov.tr). In this study, years of seniority are divided in three categories: one to ten, eleven to twenty, and twenty one or more years. 
When the table that shows the difference in the level of income of the study group is examined, it could be stated that the most remarkable finding is in the first column which contains the data of the workers whose years of seniority are less than 10 years. When we examine this column, it is seen that none of the workers whose years of seniority are low belong to the upper middle income group or high income group. In today's world where the low cost ratios became more and more important, this finding is a harbinger of a possible conflict between the people who want to employ senior workers with high cost and the people who want to decrease the costs.

Another remarkable result in the table that shows the difference in the level of income of the study group is observed in the last column which contains the data of the workers who have high years of seniority. According to this, in the study group, almost all of those who have high incomes are consisted of those who have high years of seniority.

Table 4: The Relationship between Workers' Years of Seniority and Level of Income

\begin{tabular}{|c|c|c|c|c|c|c|c|c|}
\hline \multirow{3}{*}{ Level of Income } & \multicolumn{6}{|c|}{ Years of Seniority } & & \\
\hline & \multicolumn{2}{|c|}{ 1-10 Years } & \multicolumn{2}{|c|}{ 11-20 Years } & \multicolumn{2}{|c|}{$\begin{array}{c}21 \text { Years and } \\
\text { More }\end{array}$} & \multicolumn{2}{|c|}{ Total } \\
\hline & $\mathrm{N}$ & $\%$ & $\mathrm{~N}$ & $\%$ & $\mathrm{~N}$ & $\%$ & $\mathrm{~N}$ & $\%$ \\
\hline Between 0-1000 TL & 5 & 38.5 & 2 & 1.5 & 2 & 16.7 & 9 & 5.7 \\
\hline Between 1001-1500 TL & 8 & 61.5 & 60 & 44.8 & 3 & 25.0 & 71 & 44.7 \\
\hline Between 1501-2000 TL & 0 & 0 & 66 & 49.3 & 4 & 33.3 & 70 & 44.0 \\
\hline More than $2000 \mathrm{TL}$ & 0 & 0 & 6 & 3.8 & 3 & 25.0 & 9 & 5.7 \\
\hline Total & 13 & 100 & 134 & 100 & 12 & 100 & 159 & 100 \\
\hline
\end{tabular}

The number of working people in the families of the subjects is given in the table of frequency below (Table 5) and the number of dependent people is given in Table 6 . According to the first table showing the number of working people, a great majority of the workers $(93 \%)$ provide their families' incomes on their own. The proportion of people who have a secondary person working in a wage-earning job is quite low (5.1). The number of people in the study group who have more than one person working in a wage-earning job is not significant.

When the second table showing the number of dependent people is examined in terms of the number of dependent people, the biggest group is consisted of the people who take care of four people in their families with a $50.6 \%$ proportion. It is generally such a family as the mother, father and two children. Second biggest group is consisted of the people who take 
care of five people in their families with a $23.1 \%$ proportion. The proportion of the people who have to take care of 3 people in their families is $18.1 \%$. These findings indicate that more than $90 \%$ of the subjects have to take care of other people.

When the findings such as the number of people working in wage-earning jobs, the number of dependent people and monthly incomes are evaluated together, it is possible to state that the socio-economic levels of the subjects in the study group are low.

Table 5: The Number of People in the Workers' Families Working in Wage-Earning Jobs

\begin{tabular}{|llrrr|}
\hline \multirow{4}{*}{ Valid } & & Frequency & Percent & Valid Percent \\
& 1 & 146 & 90.7 & 93.0 \\
& 2 & 8 & 5.0 & 5.1 \\
& 3 & 1 & .6 & .6 \\
& 4 & 2 & 1.2 & 1.3 \\
& Total & 157 & 97.5 & 100.0 \\
Missing & Unanswered & 4 & 2.5 & \\
& & & & \\
Total & & 161 & 100.0 & \\
\end{tabular}

Table 6: The Number of Dependent People in the Workers' Families Working in WageEarning Jobs

\begin{tabular}{|llrrr|}
\hline \multirow{4}{*}{ Valid } & & Frequency & Percent & Valid Percent \\
& 1 & 6 & 3.7 & 3.8 \\
& 2 & 7 & 4.3 & 4.4 \\
& 3 & 29 & 18.0 & 18.1 \\
& 4 & 81 & 50.3 & 50.6 \\
& 5 & 37 & 23.0 & 23.1 \\
& Total & 160 & 99.4 & 100.0 \\
\multirow{3}{*}{ Missing } & Unanswered & 1 & .6 & \\
& & & & \\
Total & & 161 & 100.0 & \\
& & & & \\
\hline
\end{tabular}

The owners of the houses that the subjects in the study group reside in are shown in Table 7. According to the findings in this table, $42.1 \%$ of the houses that the workers reside in either belong to them or to their wives. The proportion of those who live in the houses that belong to their parents is $27.7 \%$. Thus, the proportion of the people who do not need to pay for rent becomes $69.8 \%$. When it is taken into consideration that $6.9 \%$ of the study group reside in dwelling-houses with low rents, it could be stated that there is a partial financial 
welfare for the workers despite their low incomes since three-quarters of them either do not have rent costs or have low rent costs.

Table 7: The Owners of the Houses That the Workers Reside In

\begin{tabular}{|llrrr|}
\hline \multirow{3}{*}{ Valid } & Frequency & Percent & Valid Percent \\
& To My Parents & 44 & 27.3 & 27.7 \\
& To Me-My Wife & 67 & 41.6 & 42.1 \\
& Dwelling-Houses & 11 & 6.8 & 6.9 \\
& Rent & 37 & 23.0 & 23.3 \\
& Total & 159 & 98.8 & 100.0 \\
Missing & Unanswered & 2 & 1.2 & \\
Total & & 161 & 100.0 & \\
& & & & \\
\hline
\end{tabular}

\section{JOB SATISFACTION OF THE WORKERS}

Job satisfaction is an important subject for continuity and high efficiency at work. The data about the job satisfaction of the study group is shown in Table 8 below.

\section{Table 8: Social Facilities that the Workplaces Provide to the Workers}

\begin{tabular}{|c|c|c|c|c|}
\hline & & Frequency & Percent & Valid Percent \\
\hline \multirow[t]{6}{*}{ Valid } & Provides a lot & 11 & 6.8 & 6.8 \\
\hline & Provides & 30 & 18.6 & 18.6 \\
\hline & Provides to Some & 64 & 39.8 & 39.8 \\
\hline & Extent & & & \\
\hline & Provides None & 56 & 34.8 & 34.8 \\
\hline & Total & 161 & 100.0 & 100.0 \\
\hline
\end{tabular}

When Table 8 is examined, it attracts the attention that social facilities are not provided to the workers sufficiently. That is to say, $34.8 \%$ of the study group state that their organization do not provide any social facilities. On the other hand, $39.8 \%$ of them state that their organization provides social facilities to some extent. When these two groups are evaluated together, that makes $74.6 \%$ of the workers, a majority of them state that they do not receive a satisfactory support from their organization. The proportion of those who state that they receive a satisfactory support is $18.6 \%$. A smaller group with a proportion of $6.8 \%$ state that their organization provides a lot of social facilities. When these findings are evaluated together, it is clear that the workers should be supported in terms of social facilities in order to be socially strong. 
Table 9: Workers Opinions about Their Wages

\begin{tabular}{|llrrr|}
\hline \multirow{3}{*}{ Valid } & & Frequency & Percent & Valid Percent \\
& Very Good & 7 & 4.3 & 4.4 \\
& Good & 26 & 16.1 & 16.3 \\
& Normal & 80 & 49.7 & 50.0 \\
& Low & 47 & 29.2 & 29.4 \\
& Total & 160 & 99.4 & 100.0 \\
Missing & Unanswered & 1 & .6 & \\
\multirow{2}{*}{ Total } & & 161 & 100,0 & \\
& & & & \\
\hline
\end{tabular}

When Table 9 is examined, it is seen that two thirds of the workers in the sector are satisfied with their wages. $50.0 \%$ of the subjects consider that their wages are normal. The proportion of the people who consider that their wage is low is $29.4 \%$. The workers who consider that their wages are good and very good are $20.7 \%$. These findings are in parallel with Table 4 that shows the incomes and expenses of the workers. It is seen that there is an increase in the income of the worker in parallel with the increase in his years of seniority.

Table 10: Wage Satisfaction Levels of Workers

\begin{tabular}{|llrrr|}
\hline \multirow{2}{*}{ Valid } & Frequency & Percent & Valid Percent \\
& Very Satisfactory & 7 & 4.3 & 4.3 \\
& Satisfactory & 34 & 21.1 & 21.1 \\
Quite Satisfactory & 97 & 60.2 & 60.2 \\
Unsatisfactory & 23 & 14.3 & 14.3 \\
Total & 161 & 100.0 & 100.0 \\
\hline
\end{tabular}

When Table 10 is examined, it is seen that the proportion of the workers who are not satisfied with their wages are $14.3 \%$. The proportions of the workers who state that their wages are very satisfactory and satisfactory are $60.2 \%$ and $25.4 \%$ respectively. When the satisfactory options are evaluated together, it could be inferred that $85.6 \%$ of the workers are satisfied with their wages. This proportion can be considered quite high. In the light of these findings, it could be argued that wage satisfaction level of workers is sufficient.

Table 11: Workers' Desires to Work in Jobs with the Same Wages

\begin{tabular}{|llrrr|}
\hline \multirow{3}{*}{ Valid } & & Frequency & Percent & Valid Percent \\
& I don't want to. & 58 & 36.0 & 37.2 \\
& I may want to. & 33 & 20.5 & 21.2 \\
& I want to. & 54 & 33.5 & 34.6 \\
& I really want to. & 11 & 6.8 & 7.1 \\
& Total & 156 & 96.9 & 100.0 \\
\multirow{3}{*}{ Missing } & Unanswered & 5 & 3.1 & \\
Total & & 161 & 100.0 & \\
\hline
\end{tabular}


When Table 11 is examined, it is possible to see if they are satisfied with their sector or not along with their opinions about changing it. $37.2 \%$ of the study group consists of those who do not want to work in another sector. These workers show that they are quite satisfied with their working conditions. On the other hand, the proportion of the workers who state that they really want to work in another sector is $7.1 \%$. When the proportions of the workers who state that they may want to or they want to work in another sector are evaluated together, we have a $62.9 \%$. These findings indicate that $62.9 \%$ of the workers are willing to change their jobs on condition that they earn same amount of money. This group indicates the proportion of those who are not satisfied with their sector because of various reasons.

Table 12: If the Workers have a Fear of Losing their Jobs

\begin{tabular}{|llrrr|}
\hline \multirow{3}{*}{ Valid } & & Frequency & Percent & Valid Percent \\
& Never & 29 & 18.0 & 18.1 \\
& Sometimes & 81 & 50.3 & 50.6 \\
& Always & 50 & 31.1 & 31.3 \\
& Total & 160 & 99.4 & 100.0 \\
Missing & Unanswered & 1 & .6 & \\
Total & & 161 & 100.0 & \\
\hline
\end{tabular}

When Table 12 is examined, it is seen that $31.3 \%$ of the study group have a constant fear of losing their jobs. The proportion of those who sometimes have the fear of losing their jobs is also remarkable with a 50.6\%. On the other hand, the proportion of those who never have the fear of losing their jobs is $18.1 \%$ and it shows the privileged few. When these findings are taken into consideration, the proportion of those who have the fear of losing their jobs is $81.7 \%$ and it is quite high. It is a fact that the performance and motivations of the workers who have the constant fear of losing their jobs are not at the desired level.

\section{FINDINGS ABOUT THE WORKPLACE ENVIRONMENT}

Some variables about the workers working in iron-steel sector such as the health conditions of the workplace, friend relationships, labor relations, risks in the workplace and workers' concerns about the workplace were examined in this applied study and findings are presented in tables below. 
Table 13: Workplace Satisfaction Levels of Workers

\begin{tabular}{|llrrr|}
\hline \multirow{3}{*}{ Valid } & & Frequency & Percent & Valid Percent \\
& Very Satisfied & 29 & 18.0 & 18.2 \\
& Satisfied & 74 & 46.0 & 46.5 \\
& Quite Satisfied & 41 & 25.5 & 25.8 \\
& Unsatisfied & 15 & 9.3 & 9.4 \\
& Total & 159 & 98.8 & 100.0 \\
\multirow{3}{*}{ Missing } & Unanswered & 2 & 1.2 & \\
Total & & 161 & 100,0 & \\
& & & & \\
\hline
\end{tabular}

When Table 13 is examined, it is seen that all of the workers in the study group are satisfied with their working environments except for a $9.4 \%$. Those who are very satisfied constitute $18.2 \%$. When these findings are taken into consideration, it could be argued that the workplace environment in the sector is quite appropriate.

Table 14: Friend Relationships Satisfaction Levels of Workers

\begin{tabular}{|llrrr|}
\hline \multirow{3}{*}{ Valid } & Very Good & 31 & 19.3 & 19.4 \\
& Good & 54 & 33.5 & 33.8 \\
& Quite Good & 60 & 37.3 & 37.5 \\
& Not Good & 15 & 9.3 & 9.4 \\
& Total & 160 & 99.4 & 100.0 \\
Missing & Unanswered & 1 & .6 & \\
Total & & 161 & 100,0 & \\
\hline
\end{tabular}

When Table 14 is examined, it is seen that all of the workers in the study group are satisfied with their friend relationships in the workplace environment except for a $9.4 \%$. Those who think that the friend relationships are perfect in the workplace constitute $19.4 \%$. When these findings are taken into consideration, it is seen that the organizations in the sector protect and develop friend relationships.

Table 15: Workers Opinions about the Risk Levels in the Workplace

\begin{tabular}{|llrrr|}
\hline \multirow{4}{*}{ Valid } & Frequency & Percent & Valid Percent \\
& Not risky & 3 & 1.9 & 1.9 \\
& A bit risky & 32 & 19.9 & 19.9 \\
Risky & 80 & 49.7 & 49.7 \\
Too risky & 46 & 28.6 & 28.6 \\
Total & 161 & 100.0 & 100.0 \\
\hline
\end{tabular}


When Table 15 is examined, all of the workers in the study group think that their job is dangerous and risky except for a $1.9 \%$. The proportion of those who think that their job is too dangerous and risky is $28.6 \%$. Accordingly, the proportion of those who think that their job is dangerous and risky is $49.7 \%$ which includes almost half the workers. When these findings are taken into consideration, it is seen that the jobs of the workers in the study group are dangerous and risky.

\section{FINDINGS ABOUT THE HEALTH CONDITIONS OF THE WORKERS}

In the study, workers were asked if they find the workplace environment healthy and have the fear of developing a health problem in the future. Findings are presented in tables below.

Table 16: Workers Opinions about the Health Conditions of the Workplace

\begin{tabular}{|llrrr|}
\hline \multirow{3}{*}{ Valid } & Frequency & Percent & Valid Percent \\
& Not healthy & 2 & 1.2 & 1.3 \\
& A bit unhealthy & 32 & 19.9 & 20.0 \\
& Healthy & 87 & 54.0 & 54.4 \\
& Very healthy & 39 & 24.2 & 24.4 \\
& Total & 160 & 99.4 & 100.0 \\
Missing & Unanswered & 1 & .6 & \\
Total & & 161 & 100,0 & \\
& & & & \\
\hline
\end{tabular}

When Table 16 is examined, it is seen that $78.8 \%$ of the workers in the study group are healthy. Those who have some health problems constitute a $20 \%$. The proportion of those who state that they are not healthy is $1.3 \%$ which is quite low. When we take this table into consideration, it is not possible to state that there is a serious health problem in the environment where our study group lives. In other words, it seems impossible to talk about a relationship between the job and any illnesses.

Table 17: If the Workers have the Fear of Developing Any Health Problems in the Future

\begin{tabular}{|llrrr|}
\hline \multirow{3}{*}{ Valid } & & Frequency & Percent & Valid Percent \\
& Not worried & 13 & 8.1 & 8.1 \\
& A bit worried & 53 & 32.9 & 33.1 \\
& Worried & 64 & 39.8 & 40.0 \\
& Very worried & 30 & 18.6 & 18.8 \\
& Total & 160 & 99.4 & 100.0 \\
\multirow{3}{*}{ Missing } & Unanswered & 1 & .6 & \\
Total & & 161 & 100,0 & \\
& & & & \\
\hline
\end{tabular}


When Table 17 is examined, it is seen that the study group is worried about developing a health problem in the future. That is to say; $91.9 \%$ of them mentioned about being worried. The proportion of those who do not have any fears is $8.1 \%$. However, $78.8 \%$ of the workers stated in Table 16 above that their workplace environment is healthy. In reply to the question of why they are worried despite finding the environment healthy, it could be stated that they have developed friendships and gossip is common in areas which have low population.

\section{WORKERS OPINIONS ABOUT THE SECTOR}

Table 18: Workers Opinions about the Technological Equipment in Workplace

\begin{tabular}{|llrrr|}
\hline \multirow{3}{*}{ Valid } & & Frequency & Percent & Valid Percent \\
& Very Sufficient & 10 & 6.2 & 6.3 \\
& Sufficient & 40 & 24.8 & 25.2 \\
& A bit Sufficient & 79 & 49.1 & 49.7 \\
& Insufficient & 30 & 18.6 & 18.9 \\
& Total & 159 & 98.8 & 100.0 \\
\multirow{2}{*}{ Missing } & Unanswered & 2 & 1.2 & \\
Total & & 161 & 100.0 & \\
\hline
\end{tabular}

When Table 18 is examined, it is seen that $81.1 \%$ of the study group state that the technological equipment in workplaces are sufficient. As a data showing if the production includes contemporary technologies, the proportion of those who find the technological equipment in workplaces insufficient is $18.9 \%$. New technologies are keystones for the organizations to serve more effectively. With the help of technology, organizations are able to serve not only cheaper and more effectively but also in shorter time. ${ }^{1}$ In this respect, it is strategically important to follow new technologies and adapting them to business processes to achieve safer and more effective performances from the workers.

${ }^{1}$ Fidan, Yahya., "The Effect Of Technologies On The Efficiency Of Services With An Application In Turkey" Proceedings of The EMC-2000 (2000 IEEE EMS International Engineering Management Conference) Albuquerque, New Mexico, USA, August 13-15 2000, pp. 230-235, IEEE Catalog Number 00CH371392000 
Table 19: Opinions about Who Manages the Sector Better

\begin{tabular}{|llrrr|}
\hline \multirow{2}{*}{ Valid } & & Frequency & Percent & Valid Percent \\
& Private Sector Manages Better & 84 & 52.2 & 52.5 \\
& State Manages Better & 34 & 21.1 & 21.3 \\
& It doesn't matter & 39 & 24.2 & 24.4 \\
& 4 & 3 & 1.9 & 1.9 \\
& Total & 160 & 99.4 & 100.0 \\
Missing & Unanswered & 1 & .6 & \\
Total & & 161 & 100.0 & \\
\hline
\end{tabular}

When Table 19 is examined, it is seen that the study group state that sector would be managed better by the private sector. That is to say $52.5 \%$ of the subjects find that the private sector is more qualified. The proportion of those who state that it doesn't matter constitutes a considerable proportion with a $24.4 \%$.

\section{AWARENESS LEVELS OF THE WORKERS' ON THEIR PERSONNEL RIGHTS}

It is an important subject for the workers to be aware of their authorities and responsibilities that are guaranteed by the laws in order to work according to the conditions that are in their contracts and to protect themselves from forced laboring. The data showing the awareness levels of the study group on their personnel rights are presented below

Table 20: Awareness Levels of the Workers' on Their Personnel Rights Guaranteed by the Laws

\begin{tabular}{|llrrr|}
\hline \multirow{3}{*}{ Valid } & & Frequency & Percent & Valid Percent \\
& I don't know & 10 & 6.2 & 6.3 \\
& I know a bit & 52 & 32.3 & 32.5 \\
& I know & 85 & 52.8 & 53.1 \\
& I know very well & 13 & 8.1 & 8.1 \\
& Total & 160 & 99,4 & 100.0 \\
Missing & Unanswered & 1 & .6 & \\
Total & & 161 & 100.0 & \\
\hline
\end{tabular}

When Table 20 is examined, it is seen that the subjects are aware of their legal rights including annual leave, working hours and illness. The proportion of those who state that they don't know their legal rights is quite low with a $6.3 \% .53 .1 \%$ of them which constitute more than half of the subjects state that they know their legal rights, $32.5 \%$ of them state that they 
know a bit and the proportion of those who state that they know very well is $8.1 \%$. In the light of these findings, it could be argued that their awareness level on legal rights is sufficient.

\section{Table 21: If the Workers Read the Laws Regarding their Personal Rights}

\begin{tabular}{|llrrr|}
\hline & Frequency & Percent & Valid Percent \\
Valid & I haven't ever read & 5 & 3.1 & 3.1 \\
& I have read a bit & 25 & 15.5 & 15.5 \\
& I have read & 87 & 54.0 & 54.0 \\
I have read many times & 44 & 27.3 & 27.3 \\
Total & 161 & 100.0 & 100.0 \\
\hline
\end{tabular}

When Table 21 is examined, it is seen that $96.9 \%$ of the subjects have read the laws regarding their personal rights. The proportion of those who state that they haven't ever read the laws regarding their personal rights is quite low with a $3.1 \%$. With the findings in Table 21 , it is seen that the workers in the sector are quite aware of their personal rights.

\section{WORKERS' OPINIONS ABOUT THE LABOR UNIONS}

Since the labor unions is a broad topic, narrow questions such as; if the labor unions protect their rights and if the managers of labor unions work properly were asked to the study group in our applied study and the findings are presented in tables below.

Table 22: Opinions about if the Labor Unions are Effective in Protecting the Rights of the Workers

\begin{tabular}{|llrrr|}
\hline \multirow{2}{*}{ Valid } & Yes & Frequency & Percent & Valid Percent \\
& No & 79 & 49.1 & 49.7 \\
& Total & 80 & 49.7 & 50.3 \\
Missing & Unanswered & 159 & 98.8 & 100.0 \\
Total & & 2 & 1.2 & \\
\hline
\end{tabular}

When Table 22 is examined, it is seen that there are two close groups whether the labor unions are effective in protecting their rights. According to the proportions that are quite close to each other, $50.3 \%$ of the workers think that the labor unions are not effective in protecting their rights. The proportion of those who think that the labor unions are not effective in protecting their rights is $49.7 \%$. In the light of these findings, it could be argued 
that the labor unions have reliability issues. It could also be claimed that they are not effective in protecting the rights of the workers with their current practices.

Table 23: Opinions about if the Managers of Labor Unions Work Properly

\begin{tabular}{|llrrr|}
\hline \multirow{2}{*}{ Valid } & & Frequency & Percent & Valid Percent \\
& Yes & 40 & 24.8 & 25.0 \\
& No & 120 & 74.5 & 75.0 \\
& Total & 160 & 99.4 & 100.0 \\
Missing & Unanswered & 1 & .6 & \\
Total & & 161 & 100.0 & \\
\hline
\end{tabular}

When Table 23 is examined, it is seen that the subjects do not believe that the managers of labor unions work properly. $75 \%$ of them state that the managers of labor unions don't do their duties. The proportion of those who state that the managers of labor unions do their duties is only $25 \%$. In the light of these findings, it could be stated that the managers of labor unions are insufficient in some issues such as reassurance and working transparently.

\section{WORKERS' OPINIONS ABOUT THE CONTRIBUTIONS OF KARABUK UNIVERSITY TO THE SECTOR}

Although Karabuk University was founded in 2007 and is quite a young university, it started to contribute to iron-steel sector by developing training programs in order to increase knowledge and motivations of the workers working in the sector. It was asked to the study group if Karabuk University will contribute to the sector and the findings are presented in Table 24 below.

Table 24: Opinions about if Karabuk University Will Contribute to the Sector

\begin{tabular}{|llrrr|}
\hline & Frequency & Percent & Valid Percent \\
Valid & It won't contribute & 8 & 5.0 & 5.0 \\
& It will contribute a bit & 34 & 21.1 & 21.1 \\
It will contribute & 73 & 45.3 & 45.3 \\
It will contribute very much & 46 & 28.6 & 28.6 \\
Total & 161 & 100.0 & 100.0 \\
\hline
\end{tabular}

When Table 24 is examined, it is seen that the subjects trust in Karabuk University and believe that it will contribute to the sector. $95 \%$ of the subjects believe that the university will 
contribute to their sector. In the light of these findings, it should be emphasized that it is necessary to do effective studies in order to increase university - industry cooperation.

\section{RESULTS AND DISCUSSION}

In this study, socio-economic status, job satisfaction and future visions of the workers working in Karabuk Iron-Steel Industry were examined. It could be stated that the average level of education of the study group is below the medium level (below high school) but still close to it. As it could be seen in Table 3, when the workers' levels of education and wages are compared, the workers in this sector who have a high level of education have a lower level of income according to their peers working in other sectors.

According to Table 4 that shows level of income in terms of workers' years of seniority, almost all of the workers who have high incomes are consisted of those who have high years of seniority. When the findings such as the number of people working in wageearning jobs, the number of dependent people and monthly incomes are evaluated together, it is possible to state that the socio-economic levels of the subjects in the study group are low. On the other hand, it could be stated that there is a partial financial welfare for the workers despite their low incomes since three-quarters of them either do not have rent costs or have low rent costs. It could be defined with overcoming the difficulties with the strong family bounds of Turkish society and commitment to heredity and heritage traditions. But it is clear that the workers should be supported in terms of social facilities in order to be socially strong. On the other hand, there might be an increase in the income of the worker in parallel with the increase in his years of seniority. It could be stated that wage satisfaction level of workers is sufficient when it is compared with other jobs mostly because of the fear of unemployment. But still, the proportion of those who have the fear of losing their jobs is $81.7 \%$ and it is quite high. It is a fact that the performance and motivations of the workers who have the constant fear of losing their jobs are not at the desired level. At this very point, when we have a look at the state of job satisfaction, those who are very satisfied constitute $18.2 \%$. When these findings are taken into consideration, it could be argued that the workplace environment in the sector is quite appropriate. Again, it is seen that the organizations in the sector protect and develop friend relationships. As it is seen in Table 15, the jobs of the workers in the study group are dangerous and risky. This risk generally refers to occupational accidents and it is not possible to state that there is a serious health problem in the environment where our study group lives. In other words, it seems impossible to talk about a relationship between the job and any illnesses. In reply to the question of why the subjects are worried despite finding the environment healthy, it could be stated that they have developed friendships and gossip is common in areas which have low population. In this respect, it is strategically important to 
follow new technologies and adapting them to business processes to achieve safer and more effective performances from the workers.

When Table 19 is examined, it is seen that the study group state that sector would be managed better by the private sector. That is to say $52.5 \%$ of the subjects find that the private sector is more qualified. The proportion of those who state that it doesn't matter constitutes a considerable proportion with a $24.4 \%$.

According to the study, the awareness level of the workers' on their legal rights is sufficient. When Table 21 is examined, it is seen that $96.9 \%$ of the subjects have read the laws regarding their personal rights. There is almost no one who states that he hasn't ever read the laws regarding their personal rights.

Another finding in the study is that, the labor unions are not effective in protecting the rights of the workers with their current practices. It could be stated that the managers of labor unions are insufficient in some issues such as reassurance and working transparently. In the light of these findings, it should be emphasized that it is necessary to do effective studies in order to increase university - industry cooperation. Thus, $95 \%$ of the subjects believe that the university will contribute to their sector. 


\section{REFERENCES}

Allen, N. J. and Meyer, J. P. (1990a). Organizational socialization tactics: a longitudinal analysis of links to newcomers' commitment and role orientation. Academy of Management Journal, Vol: 33.

Can, Baysal Ayşen (1992). Çalışma Yaşamında İnsan, İstanbul: Avcıol Yay. NO: 225.

Castaneda, J. and Heredia, C. (1993). “The Wrong Free-Trade Deal?.” World Press Review. v. 40, Mar., s. 14-17.

Demirci, H.İ. and Kaştan, Y. (2011). 'Karabük Demir-Çelik İşletmelerinin Karabük'ün İktisadi Yaşamındaki Yeri ve Önemi', Kuruluşundan Bugüne Karabük ve Demir Çelik Sempozyumu. 2-3 Nisan 2010. Ankara.

Ersöz, H. H. (2000). 'Özelleştirmede Çalışanların Mülkiyet Sahipliği: Karabük Örneği’, Çimento Müstahsilleri İşverenleri Sendikası Haber Bülteni, 13-26.

Gürel, A. E. and Çamur, D. and Akay, A. A. (2011). 'Karabük Demir-Çelik Fabrikasının Kuruluşundan Günümüze Kent Yaşamına Ekonomik Etkileri', Kuruluşundan Bugüne Karabük ve Demir Çelik Sempozyumu, 2-3 Nisan 2010. Ankara.

Karakök, T. (2011). 'Kardemir ve Karabük', Kuruluşundan Bugüne Karabük ve Demir Çelik Sempozyumu, 2-3 Nisan 2010. Ankara.

Kütükçüoğlu, M. (2011). 'Karabük Demir Çelik Fabrikalarının Çevre ve Çalışanlar Üzerinde Sosyal Etkileri', Kuruluşundan Bugüne Karabük ve Demir Çelik Sempozyumu, 2-3 Nisan 2010. Ankara.

Özkan M. and Çabuk, S. (2011) 'Karabük Demir Çelik Fabrikaları İşçi Konutları Sorununun ve Çözüm sürecinin İncelenmesi’, Kuruluşundan Bugüne Karabük ve Demir Çelik Sempozyumu, 2-3 Nisan 2010. Ankara.

Templeman, J. and Schares, G.E. (1993). “Germany Fights Back.” Business Week. May 31 1993. 